\title{
PENGARUH LAMA FERMENTASI AMPAS PUTAK (Corypha gebanga) TERHADAP PRODUKSI GAS DAN NILAI KECERNAAN SECARA In Vitro MENGGUNAKAN Aspergillus oryzae
}

\author{
Effect Fermentation Time of Putak Dregs (Corypha gebanga) on Gas \\ Production and Digestibilty by in Vitro with Aspergillus oryzae
}

\author{
Oktiya Hariyani ${ }^{1)}$, Siti Chuzaemi ${ }^{2}$ \\ ${ }^{1)}$ Mahasiswa Fakultas Peternakan Universitas Brawijaya Jalan Veteran, Ketawanggede, Kec. Lowokwaru, Kota \\ Malang, Jawa Timur 65145 \\ ${ }^{2)}$ Dosen Fakultas Peternakan Universitas Brawijaya Jalan Veteran, Ketawanggede, Kec. Lowokwaru, Kota \\ Malang, Jawa Timur 65145 \\ Email : oktiyah@gmail.com
}

\begin{abstract}
ABSTRAK
Tujuan penelitian ini adalah untuk mengetahui pengaruh lama fermentasi ampas putak (Corypha gebanga) menggunakan Aspergillus oryzae terhadap produksi gas dan kecernaan secara in vitro. Metode penelitian yang digunakan adalah metode percobaan laboratorium menggunakan Rancangan Acak Kelompok (RAK) yang terdiri dari 5 perlakuan dan 3 kali ulangan. Perlakuan tersebut adalah PO (ampas putak tanpa perlakuan), P1 (ampas putak + 0,9\% Aspergillus oryzae difermentasi 24 jam), P2 (ampas putak $+0,9 \%$ Aspergillus oryzae difermentasi 48 jam), P3 (ampas putak $+0,9 \%$ Aspergillus oryzae difermentasi 72 jam), P4 ampas putak $+0,9 \%$ Aspergillus oryzae difermentasi 96 jam). Data yang telah diperoleh dianalisis dengan menggunakan metode analisis ragam kemudian dianalisis duncan untuk mengetahui perbedaan antar perlakuan. Hasil menunjukkan waktu fermentasi ampas putak berpengaruh sangat nyata $(P \leq 0,01)$ terhadap produksi gas dengan nilai tertinggi 134,54 ml/500 mg BK pada PO dan nilai terendah 66,37 ml/500 mg BK pada P4. Waktu fermentasi ampas putak menunjukkan hasil perbedaan sangat nyata $(P \leq 0,01)$ terhadap kecernaan bahan kering dengan nilai tertinggi yaitu 79,66\% pada P0 dan nilai terendah yaitu 49,20\% pada P4 kemudian kecernaan bahan organik dengan nilai tertinggi yaitu 79,24\% pada P0 dan nilai terendah 60,73\% pada P4. Kesimpulan dari penelitian ini adalah dengan fermentasi ampas putak selama 48 jam (P2) memberikan hasil terbaik dengan nilai total produksi gas sebanyak 86,92 ml/500 mg BK, nilai KcBK 64,13\% dan nilai KcBO 69,51\%. Sehingga waktu fermentasi ampas putak dapat menurunkan produksi gas, kecernaan bahan kering dan kecernaan bahan organik.
\end{abstract}

Kata kunci : Ampas putak, fermentasi, produksi gas, kecernaan, In vitro

How to Cite :

Hariyana, O., \& Chuzaemi, S. (2019). Pengaruh Lama Fermentasi Ampas Putak (Corypha gebanga) Terhadap Produksi Gas dan Nilai Kecernaan Secara In Vitro Menggunakan Aspergillus oryzae Jurnal Nutrisi Ternak Tropis, 2 (1) 53-62
*Corresponding author :

Oktiya Hariyani

Email : oktiyah@gmail.com

Fakultas Peternakan Universitas Brawijaya Jalan Veteran, Ketawanggede, Kec. Lowokwaru, Kota Malang, Jawa Timur 65145 


\section{ABSTRACT}

The purpose of this research was to know the effect of fermentation time of putak dregs (Corypha gebanga) using Aspergillus oryzae on gas production and digestibility of dry matter and organic matter by in vitro. The research conducted with the experimental laboratory method, using a Randomized Block Design (RBD) with 5 treatments and 3 replications. The treatments used consist of PO (putak dregs without treatment), P1 (putak dregs + 0,9\% Aspergillus oryzae fermented 24 hours), P2 (putak dregs $+0,9 \%$ Aspergillus oryzae fermented 48 hours), P3 (putak dregs $+0,9 \%$ Aspergillus oryzae fermented 72 hours) and P4 (putak dregs $+0,9 \%$ Aspergillus oryzae fermented 96 hours). The data were analyzed using analysis of variance, followed by duncan multiple range test (DMRT's). The results showed that incubation time was effected highly significant $(P \leq 0,01)$ on gas production, the highest value of gas production was 134,54 ml/500 $\mathrm{mg} \mathrm{DM}$ at P0 and the lowest value was 66,37 $\mathrm{ml} / 500 \mathrm{mg}$ $D M$ at $P 4$. Dry matter and organic matter digestibility showed was highly significant $(P \leq 0,01)$ with incubation time, the highest value of dry matter digestibility was 79,66\% at P0 and the lowest value of dry matter digestibility was 49,20\% at P4 and the highest value of organic matter digestibility was 79,24\% at P0 and the lowest value was 60,73\%. The conclusion of this research was incubation time of putak dregs fermented 48 hours $(P 2)$ gave the best result in this research with value $86,92 \mathrm{ml} / 500 \mathrm{mg}$ DM in gas production, 64,13\% in dry matter digestibility and 69,51\% in organic matter digestibility by in vitro. The incubation time of putak dregs can decrease gas production, dry matter digestibility, and organic matter digestibility.

Keywords : Putak dregs, fermented, gas production, digestibility, in vitro.

\section{PENDAHULUAN}

Pakan merupakan salah satu faktor produksi yang sangat penting, namun ketersediaannya yang terbatas dengan harga yang mahal sering menjadi kendala bagi usaha peternakan. Oleh karena itu perlu diupayakan bahan pakan alternatif yang dapat digunakan sebagai pakan ternak yang harganya murah dan tidak bersaing dengan kebutuhan manusia (Anggraeny dan Umiyasih, 2009).

Batang gewang dikenal sebagai penghasil putak yang mengandung sumber karbohidrat dan memiliki limbah ampas putak untuk ternak ruminansia. Kelompok Tsoareani Kuinbes dan Hidup Baru di Kupang, ampas putak yang diberikan kepada ternak dalam bentuk potonganpotongan kecil dan diberikan pada sore hari. Fakta tersebut menunjukkan bahwa ampas putak memiliki potensi sebagai sumber pakan yang dapat ditingkatkan kecernaannya dengan pengolahan fermentasi sebelum diberikan kepada ternak ruminansia (Soares, 2018).
Terjadi beberapa perubahanperubahan terhadap komposisi kimia pada saat proses fermentasi, seperti kandungan protein, lemak, karbohidrat, asam amino, vitamin, dan mineral sebagai akibat aktivitas dan perkembangbiakan mikroorganisme selama proses fermentasi, kelompok kapang Aspergillus merupakan kelompok mikroba yang paling dominan dalam menghidrolisis pati, kelompok kapang Aspergillus merupakan kelompok mikroba yang paling dominan dalam menghidrolisis pati (Melliawati, Rohmatussolihat dan Ferra, 2006). Aspergillus oryzae merupakan kapang yang menghasilkan enzim yaitu $\alpha-$ amilase, $\alpha$-galaktosidase, glutaminase, protease, dan $\beta$-glukosidase.

Secara umum hasil pengolahan putak oleh kapang Aspergillus niger dalam percobaan mampu memperbaiki nutrisi putak. Penerapan teknologi fermentasi terhadap bahan berkualitas rendah dapat meningkatkan kualitasnya terutama kadar protein (Hilakore, Suryahadi, IGK, Mangunwijaya, 2008). Berdasarkan latar belakang tersebut penulis ingin mengetahui 
lebih lanjut fermentasi putak menggunakan inokulum yang berbeda yaitu Aspergillus oryzae terhadap produksi gas dan nilai kecernaan bahan kering dan bahan organik secara in vitro.

\section{MATERI DAN METODE}

Materi penelitian ini adalah ampas putak, mineral, urea, Aspergillus oryzae dan cairan rumen yang diambil dari sapi betina PFH berfistula rumen. Metode penelitian yang digunakan adalah metode percobaan laboratorium menggunakan Rancangan Acak Kelompok (RAK) yang terdiri dari 5 perlakuan dan 3 kali ulangan. Perlakuan penelitian terdiri dari:

P0: Ampas putak tanpa perlakuan

P1: Ampas putak + 0,9\% Aspergillus oryzae (difermentasi 24 jam)

P2: Ampas putak + 0,9\% Aspergillus oryzae (difermentasi 48 jam)

P3: Ampas putak + 0,9\% Aspergillus oryzae (difermentasi 72 jam)

P4: Ampas putak + 0,9\% Aspergillus oryzae (difermentasi 96 jam)

Variabel yang diamati adalah produksi gas, nilai kecernaan bahan kering dan nilai kecernaan bahan organik secara in vitro. Data yang diperoleh dianalisis menggunakan analisis ragam (Analysis of variance/ANOVA). Apabila ada perbedaan maka dianalisis lanjut dengan menggunakan Uji Jarak Berganda Duncan (UJBD).

\section{HASIL DAN PEMBAHASAN}

\section{Produksi Gas In Vitro}

Produksi gas dapat digunakan untuk mengestimasi bahan pakan tercerna (Kurniawati, 2007). Produksi gas merupakan parameter aktivitas mikroba rumen dalam sintesis energi dan protein asal mikroba (Prihartini, Chuzaemi dan Sofjan, 2007). Perlakuan lama fermentasi 96 jam hari $\mathrm{P} 4$ menunjukkan total produksi gas terendah yakni $66,37 \mathrm{ml} / 500 \mathrm{mg} \mathrm{BK}$, selanjutnya urutan dari tertinggi P0 134,54 ml/500 mg BK, P1 98,25 ml/500 mg BK, P2 86,92 ml/500 mg BK dan P3 73,44 $\mathrm{ml} / 500 \mathrm{mg}$ BK. Hal tersebut menunjukkan bahwa seiring dengan bertambahnya waktu fermentasi ampas putak maka semakin rendah gas yang dihasilkan, nilai produksi gas menunjukkan penurunan pada setiap perlakuan dari P0 sampai ke P4. Hasil uji Jarak Berganda Duncan (Duncan's Multiple Range Test), maka diketahui bahwa perlakuan P4 memiliki nilai produksi gas terendah dan berbeda sangat nyata $(\mathrm{P} \leq 0,01)$ terhadap perlakuan $\mathrm{P} 0, \mathrm{P} 1$ dan $\mathrm{P} 2$, perlakuan $\mathrm{P} 4$ tidak menunjukkan perbedaan sangat nyata $(\mathrm{P} \leq 0,01)$ dengan $\mathrm{P} 3$.

Perlakuan P0 memiliki hasil produksi gas tertinggi dibandingkan dengan perlakuan lain. Grafik hubungan waktu fermentasi terhadap nilai produksi gas inkubasi 48 jam (Gambar 1) menunjukkan $\mathrm{R}^{2}$ sebesar $90,3 \%$ menandakan bahwa pengaruh lama fermentasi ampas putak menggunakan Aspergillus oryzae berpengaruh $90,3 \%$ terhadap nilai produksi total produksi gas dan sisanya 9,7\% dipengaruhi oleh faktor lain, berdasarkan grafik regresi linear setiap kenaikan 1 jam lama fermentasi ampas putak menggunakan Aspergillus oryzae menurunkan nilai produksi gas sebesar $0,6715 \mathrm{ml} / 500 \mathrm{mg} \mathrm{BK}$. Nilai produksi gas pada interval waktu 4,8 , 12, 24, 36 dan 48 jam inkubasi ditunjukkan pada Tabel 1.

Peningkatan produksi gas signifikan terjadi pada masa inkubasi jam ke-4 untuk P1, P2, P3, dan P4 kemudian P0 mengalami peningkatan produksi gas tinggi pada jam ke-12 dan pada inkubasi ke-48 P0 menunjukkan peningkatan produksi gas tertinggi, menurut Citra (2012) produksi gas total semakin meningkat seiring dengan meningkatnya waktu inkubasi (48 jam). Peningkatan produksi gas berjalan linier pada inkubasi 4 sampai 12 jam dan berjalan melambat pada inkubasi 24 ke-48 jam. Pelambatan produksi gas ini menunjukkan substrat yang dapat difermentasi semakin berkurang jumlahnya sehingga produksi VFA mulai berkurang yang mengindikasikan mulai menurunnya 
ketersediaan energi bagi ternak ruminansia. Produksi gas merupakan parameter aktivitas mikroba rumen dalam sintesis energi dan protein asal mikroba (Prihartini, dkk, 2007). Produksi gas yang dihasilkan dari pakan yang difermentasi dapat mencerminkan kualitas pakan tersebut. Bahrin, Destilia dan Pertiwi (2011) menyatakan bahwa proses penguraian oleh mikroorganisme untuk menguraikan bahan-bahan organik terjadi secara anaerob. Prinsipnya proses anaerob adalah proses biologi yang berlangsung pada kondisi tanpa oksigen oleh mikroorganisme yang mampu mengubah senyawa organik menjadi gas. Semua jenis bahan organik yang mengandung senyawa karbohidrat, protein, dan lemak bisa diproses untuk menghasilkan gas.

Tabel 1. Nilai Produksi Gas pada berbagai waktu inkubasi.

\begin{tabular}{|c|c|c|c|c|c|c|}
\hline \multirow[b]{2}{*}{$\begin{array}{c}\text { Perlak } \\
\text { uan } \\
\end{array}$} & \multicolumn{6}{|c|}{ Inkubasi (Jam) } \\
\hline & $\begin{array}{c}4(\mathrm{ml} / 500 \\
\mathrm{mg} \mathrm{BK})\end{array}$ & $\begin{array}{c}8(\mathrm{ml} / 500 \\
\mathrm{mg} \mathrm{BK})\end{array}$ & $\begin{array}{c}12(\mathrm{ml} / 500 \\
\mathrm{mg} \mathrm{BK})\end{array}$ & $\begin{array}{c}24(\mathrm{ml} / 500 \\
\mathrm{mg} \mathrm{BK})\end{array}$ & $\begin{array}{c}36(\mathrm{ml} / 500 \\
\mathrm{mg} \mathrm{BK})\end{array}$ & $\begin{array}{c}48(\mathrm{ml} / 500 \\
\mathrm{mg} \mathrm{BK})\end{array}$ \\
\hline P0 & $\begin{array}{c}4,25 \pm \\
0,26 \\
1749+\end{array}$ & $\begin{array}{l}16,26 \pm \\
2,13 \\
\end{array}$ & $51,11 \pm 3,74$ & $89,45 \pm 6,16$ & $\begin{array}{c}124,58 \pm \\
8,09\end{array}$ & $\begin{array}{c}134,54 \pm \\
8,09^{\mathrm{d}} \\
9825+\end{array}$ \\
\hline $\mathrm{P} 1$ & $\begin{array}{c}2,07 \\
15,13 \pm\end{array}$ & $\begin{array}{c}2,06 \\
25,21 \pm\end{array}$ & $54,87 \pm 0,59$ & $62,31 \pm 4,18$ & $86,66 \pm 3,56$ & $\begin{array}{c}3,57^{\mathrm{c}} \\
86,92 \pm\end{array}$ \\
\hline $\mathrm{P} 2$ & $\begin{array}{c}0,80 \\
15,44 \pm\end{array}$ & $\begin{array}{c}1,72 \\
23,38 \pm\end{array}$ & $38,36 \pm 3,06$ & $51,28 \pm 1,75$ & $78,15 \pm 0,93$ & $\begin{array}{c}0,96^{\mathrm{bc}} \\
73,44 \pm\end{array}$ \\
\hline P3 & $\begin{array}{c}2,04 \\
12,90 \pm\end{array}$ & $\begin{array}{c}2,41 \\
22,26 \pm\end{array}$ & $33,39 \pm 2,67$ & $40,59 \pm 4,74$ & $64,22 \pm 5,78$ & $\begin{array}{c}5,79^{\mathrm{ab}} \\
66,37 \pm\end{array}$ \\
\hline $\mathrm{P} 4$ & 2,32 & 2,60 & $32,17 \pm 3,26$ & $37,41 \pm 2,31$ & $57,66 \pm 2,58$ & $2,55^{\mathrm{a}}$ \\
\hline
\end{tabular}

Keterangan : Superskrip yang berbeda pada kolom yang sama menunjukkan perbedaan yang sangat nyata $(\mathrm{P} \leq 0,01)$

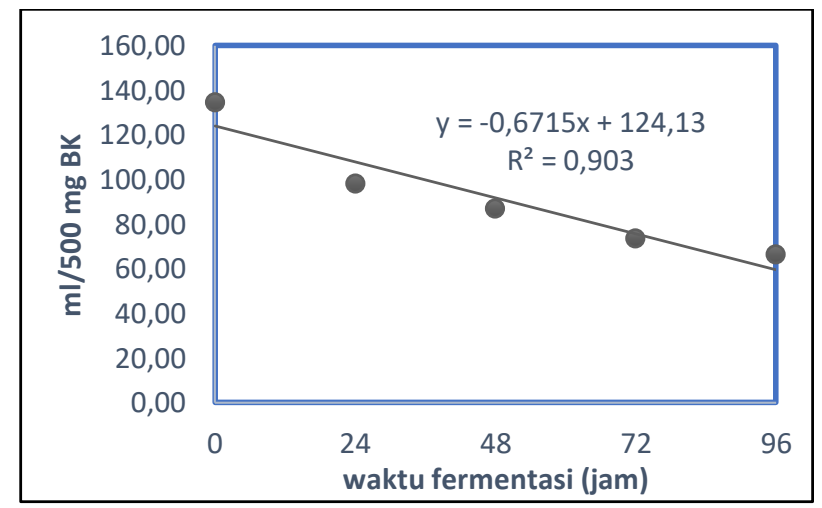

Gambar 1. Grafik hubungan waktu fermentasi terhadap nilai produksi gas inkubasi 48 jam.

Hasil menunjukkan bahwa perlakuan (P0) memiliki bahan organik yang lebih tinggi dari perlakuan yang lain sehingga total produksi gas yang diperoleh lebih tinggi dari perlakuan 1 sampai dengan 4. Perlakuan 1 (P1) sampai dengan perlakuan 4 (P4) hasil produksi gas mengalami penurunan, hal ini menunjukkan bahwa aktivitas mikroba dalam mencerna pakan menurun pada perlakuan 1 sampai dengan 4 dikarenakan degradasinya yang rendah, sesuai dengan pernyataan Assakur (2013) menyatakan bahwa gas yang rendah berhubungan dengan tingkat degradasinya yang juga rendah. Produksi gas yang dihasilkan menggambarkan aktivitas 
mikroba rumen dalam mencerna pakan. Produksi gas pada perlakuan 1 sampai dengan 4 menurun karena kandungan serat kasar yang meningkat, menurut Yuliana (2018) ampas putak yang difermentasi menggunakan Aspergillus oryzae 0,9\% meningkatkan serat kasar dengan hasil yaitu P0 (7,38\%), P1 (8,59\%), P2 (15,14\%), P3 $(19,22 \%)$ dan P4 (17,28\%). Sesuai dengan pendapat Nurjannah, Ayuningsih dan Hernaman (2016) bahwa rendahnya rataan nilai total produksi gas hasil penelitian kemungkinan disebabkan oleh kualitas ransum yang rendah, yang ditandai oleh kandungan serat yang tinggi.

\section{Nilai potensi Produksi Gas dan Laju Produksi Gas}

Nilai potensi produksi gas merupakan nilai yang digunakan untuk melihat potensi bahan organik yang dapat dicerna didalam rumen dan nilai c merupakan nilai laju produksi gas yang terjadi pada waktu inkubasi 0-48 jam (Khoiriyah, Chuzaemi dan Sudarwati, 2016). Hasil analisis potensi produksi gas dan laju produksi gas disajikan pada Tabel 2.

Tabel 2. Rataan Nilai Potensi Produksi gas (b) dan Laju Produksi Gas (c).

\begin{tabular}{ccc}
\hline Perlakuan & $\mathrm{b}(\mathrm{ml} / 500 \mathrm{mg} \mathrm{BK})$ & $\mathrm{c}(\mathrm{ml} / \mathrm{jam})$ \\
\hline P0 & $268,79 \pm 6,492^{\mathrm{d}}$ & $0,016 \pm 0,002^{\mathrm{a}}$ \\
P1 & $106,6 \pm 7,173^{\mathrm{bc}}$ & $0,046 \pm 0,004^{\mathrm{c}}$ \\
P2 & $117,58 \pm 9,324^{\mathrm{c}}$ & $0,029 \pm 0,005^{\mathrm{b}}$ \\
P3 & $91,05 \pm 16,959^{\mathrm{ab}}$ & $0,034 \pm 0,008^{\mathrm{b}}$ \\
P4 & $85,73 \pm 10,954^{\mathrm{a}}$ & $0,033 \pm 0,008^{\mathrm{b}}$ \\
\hline
\end{tabular}

Keterangan : Superskrip yang berbeda pada kolom yang sama menunjukkan perbedaan yang sangat nyata $(\mathrm{P} \leq 0,01)$.

Hasil analisis ragam terhadap rata-rata nilai potensi (b) produksi gas menunjukkan pengaruh berbeda sangat nyata $(\mathrm{P} \leq 0,01)$. Hasil uji Jarak Berganda Duncan (Duncan's Multiple Range Test) menunjukkan P0 sangat berbeda nyata dengan P2, P2 tidak berbeda nyata dengan P1, P1 tidak berbeda nyata dengan P3, P3 tidak berbeda nyata dengan P4. Nilai b tertinggi pada perlakuan P0 yaitu ampas putak tanpa fermentasi yaitu $268,79 \mathrm{ml} / 500 \mathrm{mg}$ BK sejalan dengan tingginya produksi gas perlakuan tersebut. Mukmin, Hendrawan, Kusmartono dan Mashudi (2014) menyatakan nilai parameter b yang tinggi menunjukkan tingginya partikel pakan yang tidak terlarut tetapi berpotensi terfermentasi di dalam rumen sehingga menghasilkan gas. Menurut Makkar (2004) nilai b produksi gas tergantung pada proporsi partikel, tidak larut tetapi dapat terdegradasi, dan tidak dapat terdegradasi dari pakan.

Hasil analisa penelitian kami menunjukkan adanya peningkatan serat kasar dari perlakuan $\mathrm{P} 0 ; 7,38 \%, \mathrm{P} 1 ; 8,59 \%$, P2; $15,14 \%$, P3; 19,22\% dan P4; 17,28\% peningkatan serat kasar tersebut mempengaruhi nilai protensi produksi gas. Wati, Achmadi dan Pangestu (2012) menyatakan bahwa tinggi rendahnya nilai fraksi b dipengaruhi komponen serat. Nilai laju produksi gas (c) dari hasil penelitian menunjukkan pengaruh berbeda sangat nyata $(\mathrm{P} \leq 0,01)$. Hasil uji jarak berganda Duncan (Duncan's Multiple Range Test) menunjukkan P1 berbeda sangat nyata dengan P4, P3, P2 dan P0, P4 tidak berbeda nyata dengan $\mathrm{P} 3$ dan $\mathrm{P} 2$, nilai laju produksi gas tertinggi yaitu perlakuan P1 yaitu 0,046 $\mathrm{ml} / \mathrm{jam}$. Laju produksi gas in vitro semakin berkurang seiring dengan meningkatnya waktu inkubasi, disebabkan substrat yang dapat difermentasi juga semakin berkurang jumlahnya (Jayanegara, Sofyan, Makkar, dan Becker, 2009). Nilai c yang tinggi menunjukkan bahwa pakan tersebut didegradasi dengan cepat dalam satuan waktu tertentu. 
Nilai Kecernaan Bahan Kering (KcBK) dan Kecernaan Bahan Organik (KcBO) Residu Produksi Gas Inkubasi 48 jam secara In vitro

Untuk mengetahui nilai kecernaan pakan dapat diukur dengan teknik in vitro. Teknik in vitro merupakan teknik pengukuran kecernaan yang dapat dilakukan di laboratorium dengan meniru kondisi rumen sebenarnya (Mulyawati, 2009). Nilai kecernaan adalah tanda awal ketersediaan nutrien dalam bahan pakan ternak tertentu. Kecernaan yang tinggi menunjukkan besarnya nutrien yang disalurkan pada ternak, sedangkan kecernaan yang rendah menunjukkan bahan pakan tersebut belum bisa memberikan nutrien bagi ternak baik untuk hidup pokok ataupun untuk produksi. Kecernaan dapat dinyatakan dalam bentuk bahan kering dan organik sehingga dalam persentase dapat disebut koefisien cerna (Jovitry, 2011). Rataan kecernaan bahan kering dan kecernaan bahan organik disajikan pada Tabel 3.

Hasil analisis ragam kecernaan bahan kering menunjukkan bahwa fermentasi pada ampas putak berpengaruh sangat nyata $(\mathrm{P} \leq 0,01)$ terhadap nilai kecernaan bahan kering. Hasil uji Jarak Berganda Duncan (Duncan's Multiple Range Test), diketahui bahwa perlakuan P4 memiliki nilai kecernaan bahan kering terendah yaitu 49 , $20 \%$ dan berbeda sangat nyata $(\mathrm{P} \leq 0,01)$ terhadap perlakuan $\mathrm{P} 0, \mathrm{P} 1, \mathrm{P} 2$ dan $\mathrm{P} 3$. Perlakuan P0 memiliki nilai kecernaan tertinggi yaitu $79,66 \%$ dan berbeda sangat nyata $(\mathrm{P} \leq 0,01)$ terhadap $\mathrm{P} 1 \quad(71,41 \%), \mathrm{P} 2$
$(64,13 \%)$, P3 $(56,88 \%)$ dan P4 $(49,20 \%)$. Nilai KcBK ampas putak (Gambar 2) memiliki nilai $\mathrm{R}^{2}$ sebesar $99,95 \%$, hal tersebut menandakan bahwa pengaruh lama fermentasi ampas putak berpengaruh 99,95\% terhadap nilai $\mathrm{KcBK}$ dan sisanya $0,05 \%$ dipengaruhi oleh faktor lain. Berdasarkan grafik regresi linear setiap kenaikan 1 jam lama fermentasi ampas putak menggunakan Aspergillus oryzae menurunkan nilai Kecernaan Bahan Kering sebesar $0,31 \%$. Grafik hubungan waktu fermentasi terhadap nilai $\mathrm{KcBK}$ ampas putak dapat dilihat pada Gambar 2.

Penurunan KcBK dipengaruhi oleh peningkatan serat dari P0 sampai P4. Sembiring (2006) menyatakan besarnya kecernaan pakan di dalam rumen dipengaruhi oleh komposisi kimia pakan terutama kandungan serat dan protein, dan kondisi fermentasi meliputi $\mathrm{pH}, \mathrm{N}-\mathrm{NH} 3$, dan VFA yang mendukung terjadinya kecernaan pakan selama proses fermentasi. Kandungan serat yang lebih rendah menyebabkan kecernaan bahan kering lebih tinggi. Tingkat kecernaan pakan dapat digunakan sebagai indikator kualitas pakan. Semakin tinggi kecernaan bahan kering dan bahan organik pakan semakin tinggi nutrien yang dapat digunakan untuk memenuhi kebutuhan nutrisi ternak. Menurut Suparwi (2000) suatu bahan pakan dikatakan fermentable apabila kecernaan bahan keringnya minimun $60 \%$. Hasil penelitian menunjukkan bahwa perlakuan P0, P1 dan P2 merupakan pakan yang fermentable.

Tabel 3. Rataan kecernaan bahan kering (KcBK) dan kecernaan bahan organik (KcBO)

\begin{tabular}{ccc}
\hline Perlakuan & KcBK $(\%)$ & KcBO $(\%)$ \\
\hline P0 & $79,66 \pm 0,37^{\mathrm{e}}$ & $79,24 \pm 1,648^{\mathrm{c}}$ \\
P1 & $71,41 \pm 0,05^{\mathrm{d}}$ & $77,00 \pm 0,585^{\mathrm{c}}$ \\
P2 & $64,13 \pm 2,03^{\mathrm{c}}$ & $69,51 \pm 1,990^{\mathrm{b}}$ \\
P3 & $56,88 \pm 0,98^{\mathrm{b}}$ & $66,09 \pm 1,720^{\mathrm{b}}$ \\
P4 & $49,20 \pm 0,50^{\mathrm{a}}$ & $60,73 \pm 2,181^{\mathrm{a}}$ \\
\hline
\end{tabular}

Keterangan 'Superskrip yang berbeda pada kolom yang sama menunjukkan perbedaan yang sangat nyata $(\mathrm{P} \leq 0,01)$. 


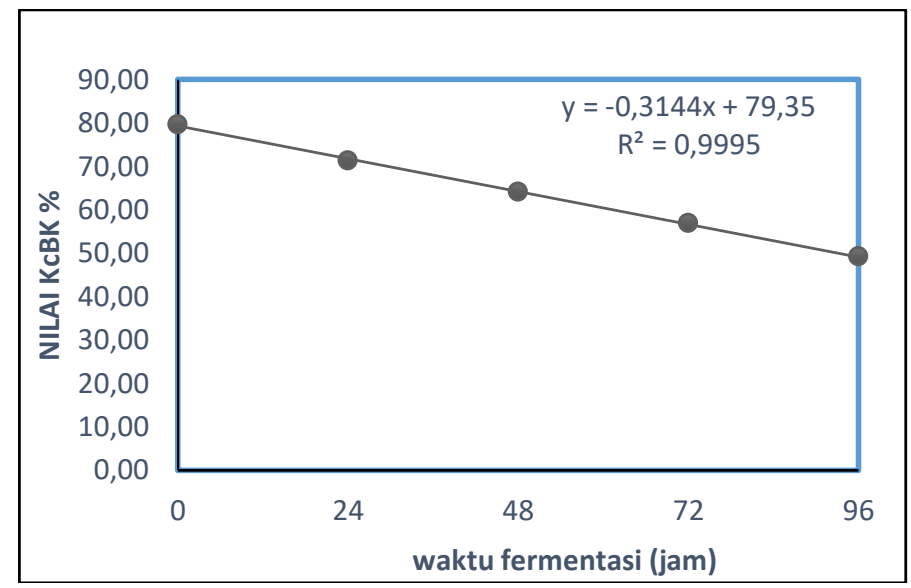

Gambar 2. Grafik hubungan waktu fermentasi terhadap nilai KcBK ampas putak

Hasil analisis ragam Tabel 3 . kecernaan bahan organik menunjukkan pengaruh perbedaan yang sangat nyata $(\mathrm{P} \leq 0,01)$ pada waktu fermentasi ampas putak terhadap nilai kecernaan bahan organik. Berdasarkan hasil Uji Jarak Berganda Duncan (Duncan's Multiple Range Test), maka diketahui bahwa nilai kecernaan bahan organik terendah adalah perlakuan $\mathrm{P} 4$ dengan nilai berbeda sangat nyata $(P \leq 0,01)$ terhadap semua perlakuan. Perlakuan P0 $(79,24 \%)$ memiliki nilai kecernaan bahan organik tertinggi tetapi tidak berbeda nyata terhadap P1 $(77,00 \%)$, kemudian P2 $(69,51 \%)$ (tidak berbeda nyata dengan P3 $(66,09 \%), \quad$ P4 $(60,73 \%)$ (memiliki nilai kecernaan bahan organik terendah dan berbeda sangat nyata terhadap P0, P1, P2 dan P3). Grafik hubungan waktu fermentasi terhadap nilai $\mathrm{KcBO}$ ampas putak (Gambar 3) memiliki nilai $\mathrm{R}^{2}$ sebesar 97,96\%, hal tersebut menandakan bahwa pengaruh lama fermentasi ampas putak berpengaruh terhadap nilai $\mathrm{KcBO}$ dan sisanya $2,04 \%$ dipengaruhi oleh faktor lain berdasarkan grafik regresi linear setiap kenaikan 1 jam waktu fermentasi ampas putak menggunakan Aspergillus oryzae menurunkan nilai Kecernaan Bahan Organik sebesar $0,2 \%$. Hal ini menunjukkan bahwa perlakuan P0 memiliki nilai kecernaan bahan organik terbaik $(79,24 \%)$ diantara semua perlakuan, sedangkan perlakuan P4 memiliki nilai kecernaan bahan organik terendah $(60,73 \%)$. Lama fermentasi ampas putak menggunakan Aspergillus oryzae dengan interval waktu 24 jam, 48 jam, 72 jam dan 96 jam menunjukkan tren penurunan nilai kecernaan bahan organik. Grafik hubungan waktu fermentasi terhadap nilai KcBO ampas putak dapat dilihat pada Gambar 3.

Bahan organik menghasilkan energi untuk pertumbuhan dan perkembangan ternak. Kecernaan bahan organik diukur karena komponen dari bahan organik sangat dibutuhkan ternak untuk hidup pokok dan produksi. Bahan organik menghasilkan energi untuk pertumbuhan dan perkembangan ternak. Semakin tinggi nilai kecernaan suatu bahan pakan maka semakin banyak zat nutrien yang diserap tubuh ternak (Silalahi, 2003).

Penurunan nilai kecernaan bahan organik pada perlakuan P1 sampai dengan P4 berkaitan dengan penurunan $\mathrm{KcBK}$ perlakuan tersebut. Menurut penelitian Dewi, Mukodiningsih dan Sutrisno (2012) penurunan kecernaaan bahan organik diduga karena kemampuan mikroba rumen dalam menerima nutrisi telah melebihi batas maksimal sehingga mikroba rumen tidak mampu memanfaatkan berdampak pada penurunan aktivitas mikroba rumen. 


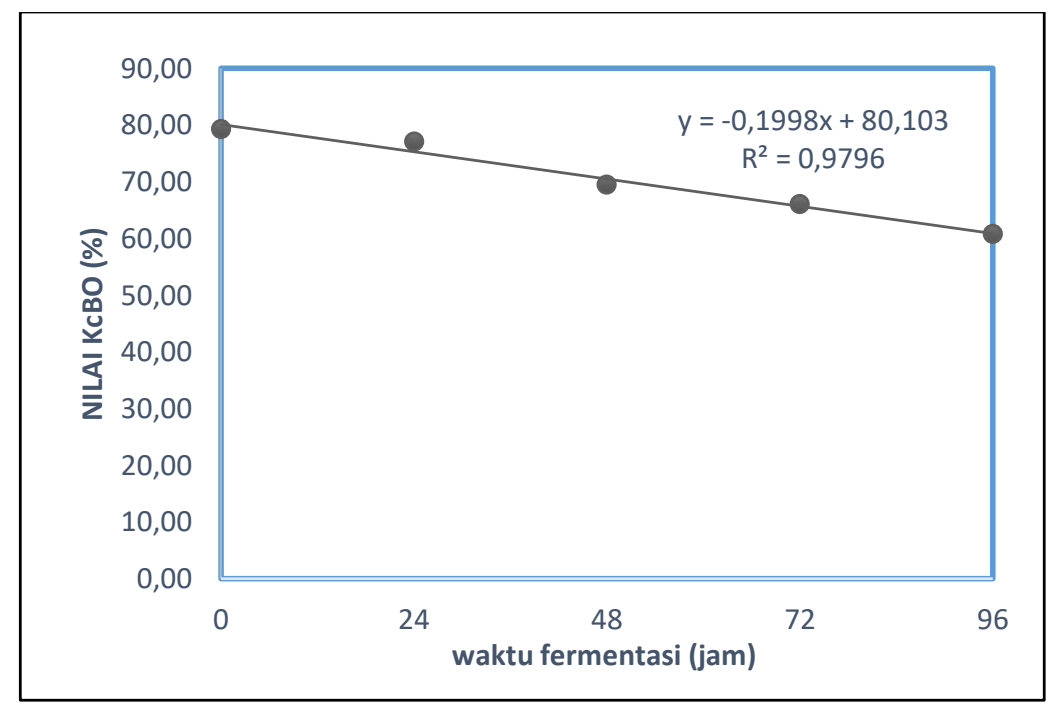

Gambar 3. Grafik hubungan waktu fermentasi terhadap nilai KcBO ampas putak

Mikroba rumen mendegradasi bahan kering dan bahan organik khususnya karbohidrat dan hasil dari proses tersebut digunakan mikroba sebagai sumber karbon dan energi untuk menunjang pertumbuhannya. Syahrir, Rasjid, Mide dan Harfiah (2012) menyatakan bahwa semakin tinggi kecernaan bahan organik pakan maka semakin tinggi nutrien yang dapat digunakan untuk memenuhi kebutuhan nutrisi ternak.

\section{KESIMPULAN DAN SARAN}

\section{Kesimpulan}

Berdasarkan keseluruhan hasil penelitian dapat disimpulkan bahwa:

1. Semakin lama fermentasi ampas putak menggunakan Aspergillus oryzae 0,9\% maka hasil nilai Produksi Gas semakin menurun. Perlakuan P2 yang difermentasi selama 48 jam merupakan perlakuan terbaik dengan nilai total produksi gas 86,92 (ml/500 mg BK).

2. Semakin lama fermentasi ampas putak menggunakan Aspergillus oryzae 0,9\% nilai Kecernaan Bahan Kering dan nilai Kecernaan Bahan Organik ampas putak semakin menurun. Perlakuan P2 yang difermentasi selama 48 jam merupakan perlakuan terbaik dengan nilai $\mathrm{KcBK}$ $64,13 \%$ dan nilai $\mathrm{KcBO} 69,51 \%$.

\section{Saran}

1. Untuk meningkatkan kualitas pakan ampas putak (Corypha gebanga) perlu adanya pengolahan, salah satunya dengan metode fermentasi selama 48 jam menggunakan inokulum Aspergillus oryzae $0,9 \%$.

2. Diperlukan penelitian lebih lanjut secara in vivo untuk mengetahui palatabilitas ampas putak fermentasi.

\section{DAFTAR PUSTAKA}

Anggraeny, Y. N., \& Umiyasih, U. (2009). Pengaruh Fermentasi Saccharomyces cerevisiae Terhadap Kandungan Nutrisi dan Kecernaan Ampas Pati Aren (Arenga pinnata Merr.). Prosiding Seminar Nasional Teknologi Peternakan dan Veteriner.

Assakur, M. (2013). Degradasi Bahan Kering, Nilai pH dan Produksi Gas Sistem Rumen In vitro Terhadap kulit Buah Kakao (Theobroma cacao) yang Diberi Perlakuan berbeda. Makasar: Skripsi. Fakultas Peternakan Universitas Hassanudin.

Bahrin, D., Destilia, A., \& Pertiwi, M. B. (2011). Pengaruh Jenis Sampah, Komposisi Masukan Dan Waktu Tinggal Terhadap Komposisi Biogas Dari Sampah Organik Pasar Di Kota 
Palembang (3rd ed.). Fakultas Teknik Universitas Sriwijaya: Prosiding Seminar Nasional AVoER.

Citra, D. F. (2012). Karakteristik In Vitro dan Produksi Gas Test Serat Kelapa Sawit yang Difermentasi Dengan Pleurotus ostreatus Untuk Pakan Hijauan Alternatif. Skripsi. Institut Pertanian Bogor.

Dewi, N. K., Mukodiningsih, S., \& Sutrisno, C. I. (2012). Pengaruh fermentasi kombinasi jerami padi dan jerami jagung dengan aras isi rumen kerbau terhadap kecernaan bahan kering dan bahan organik secara in vitro. Animal Agriculture Journal, 1(2), 134-140.

Hilakore, M. A., Suryahadi., Wiryawan, I., \& Mangunwijaya, D. (2008). Pengaruh level inokulan dan lama inkubasi oleh aspergillus niger terhadap kandungan nutrisi putak. PARTNER, 15(1), 1-4.

Jayanegara, A., Sofyan, A., Makkar, H. P. S., \& Becker, K. (2010). Kinetika produksi gas, kecernaan bahan organik dan produksi gas metana in vitro pada hay dan jerami yang disuplementasi hijauan mengandung tanin. Media Peternakan, 32(2), 120-129.

Jovitry, I. (2011). Fermentabilitas dan Kecernaan In Vitro Daun Tanaman Indigofera sp yang Mendapat Perlakuan Pupuk Cair untuk daun. Skripsi. Departemen Ilmu Nutrisi dan Teknologi Pakan. Fakultas Peternakan. Institut Pertanian Bogor.

Khoiriyah, M., Chuzaemi, S., \& Sudarwati, H. (2016). Effect of flour and papaya leaf extract (carica papaya 1.) addition to feed on gas production, digestibility and energy values in vitro. TERNAK TROPIKA Journal of Tropical Animal Production, 17(2), 74-85. https://doi.org/10.21776/ub.jtapro.2016.017.02.10
Kurniawati, A. (2013). Teknik produksi gas in-vitro untuk evaluasi pakan ternak: volume produksi gas dan kecernaan bahan pakan. Jurnal Ilmiah Aplikasi Isotop Dan Radiasi, 3(1), 40-49. https://doi.org/10.17146/JAIR.2007.3.1.552

Makkar, H, P, S. (2004). Recent advances in the in vitro gas method for evaluation of nutritional quality of feed resources. Austria: International Atomic Energy Agency Vienna.

Melliawati, R., Rohmatussolihat, \& Ferra. (2006). Seleksi mikroorganisme potensial untuk fermentasi pati sagu. Biodiversitas, 7(2), 101-104.

Mukmin, A., Hendrawan, S., Kusmartono, \& Mashudi. (2014). Produksi gas in vitro asam amino metionin terproteksi dengan serbuk mimosa sebagai sumber condensed tannin (CT). TERNAK TROPIKA Journal of Tropical Animal Production, 15(2), 36-43.

Mulyawati, Y. (2009). Fermentabilitas dan Kecernaan In Vitro Biomineral Dienkapsulasi. Skripsi. Fakultas Peternakan, Institut Pertanian Bogor.

Nurjannah, S. (2016). Pengaruh tingkat penambahan complete rumen modifier (CRM) dalam ransum berbasis pucuk tebu (saccharum officinarum) terhadap degradasi bahan kering dan produksi gas metan (in vitro). Students E-Journal, 5(2).

Prihartini, I., Chuzaemi, S., \& Sofjan, O. (2007). Parameter fermentasi rumen dan produksi gas in vitro jerami padi hasil fermentasi inokulum lignochloritik. Jurnal Protein, 15(1), 24-32.

Sembiring, P. (2006). Biokonversi limbah pabrik minyak inti sawit dengan Phanerochaetae chrysosporium dan implikasinya terhadap performans ayam broiler. Bandung: Disertasi Universitas Padjajaran. 
Silalahi, R. E. (2003). Uji Feremntabilitas dan Kecernaan In-vitro Suplemen Zn Anorganik dan Zn Organik dalam Ransum Ruminansia.

Soares, D. (2018). Pengaruh Jenis Inokulum Aspergillus niger, Saccharomyces cerevisiae dan Lama Fermentasi Terhadap Komposisi Nutrisi Ampas Putak (Corypha gebanga) dan Aplikasinya Sebagai Pakan Ayam Pedaging. Malang: Tesisi Fakultas Peternakan. Universitas Brawijaya.

Suparwi. (2000). Pengaruh minyak kelapa dan kembang sepatu (hibiscus rosasinensis) terhadap kecernaan ransum dan jumlah protozoa. Animal Production, 2(2), 53-59.
Syahrir, S., Rasjid, S., Mide, M. Z., \& Harfiah. (2016). Perubahan terhadap kadar air, berat segar dan berat kering silase pakan lengkap berbahan dasar jerami padi dan biomassa murbei. Buletin Nutrisi Dan Makanan Ternak, 10(1), 20-24.

Wati, N. E., Achmadi, J., \& Pangestu, E. (2012). Degradasi nutrien bahan pakan limbah pertanian dalam rumen kambing secara in sacco. Animal Agriculture Journal, 1(1), 485-498.

Yuliana, A. (2018). Pengaruh Lama Fermentasi Ampas Putak (Corypha gebanga) Menggunakan Aspergillus oryzae Terhadap Kualitas Fisik dan Kualitas Kimia. Malang: Skripsi. Universitas Brawijaya. 